\title{
Surveying agrifood stakeholders to identify priorities as part of a Virginia food system assessment
}

\author{
Matthew C. Benson,* Department of Agricultural \& Extension Education, Virginia Tech \\ Lisa S. Hightower, Department of Agricultural \& Extension Education, Virginia Tech \\ Eric S. Bendfeldt, Virginia Cooperative Extension, Northern District Office \\ Crystal Tyler-Mackey, Virginia Cooperative Extension, Southeast District Office \\ Kim L. Niewolny, Department of Agricultural \& Extension Education, Virginia Tech \\ Gordon Groover, Department of Agricultural \& Applied Economics, Virginia Tech
}

Submitted 8 February 2012 / Revised 16 June and 31 July 2012 / Accepted 2 August 2012 / Published online 17 December 2012

Citation: Benson, M. C., Hightower, L. S., Bendfeldt, E. S., Tyler-Mackey, C., Niewolny, K. L., \& Groover, G. (2012).

Surveying agrifood stakeholders to identify priorities as part of a Virginia food system assessment. Journal of Agriculture,

Food Systems, and Community Development, 3(1), 215-233. http://dx.doi.org/10.5304/jafscd.2012.031.012

Copyright (C) 2012 by New Leaf Associates, Inc.

\footnotetext{
* Corresponding author: Matthew C. Benson, Department of Agricultural \& Extension Education, Virginia Tech; 2270 Litton Reaves Hall; Blacksburg, Virginia 24061 USA; +1-540522-0762; mcbenson@,vt.edu
}

Lisa S. Hightower, Department of Agricultural \& Extension Education, Virginia Tech, 2270 Litton Reaves Hall, Blacksburg, Virginia 24061 USA

Eric S. Bendfeldt, Virginia Cooperative Extension, Northern District Office, 2322 Blue Stone Hills Drive, Suite 140, Harrisonburg, Virginia 22801 USA

Crystal Tyler-Mackey, Virginia Cooperative Extension, Southeast District Office, 2810 N. Parham Road, Suite 300, Richmond, Virginia 23294 USA

Kim L. Niewolny, Department of Agricultural \& Extension Education, Virginia Tech, 282 Litton Reaves Hall, Blacksburg, Virginia 24061 USA

Gordon Groover, Department of Agricultural \& Applied Economics, Virginia Tech, 301-A Hutcheson Hall, Blacksburg, Virginia 24061 USA

\begin{abstract}
Throughout Virginia there are a multitude of social, environmental, and economic challenges facing farmers and communities. In 2010 and 2011, an interdisciplinary team of faculty, practitioners, and graduate students collaborated to address these challenges through the creation of the Virginia Farm to Table Plan. As part of the plan, the team completed a comprehensive food system assessment. Comprehensive food system assessments use qualitative and quantitative methodologies to analyze the systematic nature of a local, state, or regional food system to address the interactions of food with social, environmental, and economic concerns. The overall purpose of this article is to present the results of an online survey of Virginia agrifood system stakeholders that investigated their priorities for strengthening Virginia's local and regional food systems. A total of 1,134 Virginia respondents completed the online survey.
\end{abstract}


Respondents were asked to rank 34 items in four major categories in terms of their level of importance for strengthening Virginia's food systems. Respondents rated increasing the "understanding by government officials of the economic, environmental, and social issues surrounding local food systems" as the most important priority among all of the items listed. The category with the most highly rated items was "food system planning, management, and policy." This survey provided key information for developing the Virginia Farm to Table Plan.

\section{Keywords}

community food systems, comprehensive food system assessment, food system planning, survey, Virginia

\section{Introduction}

Throughout Virginia, there are a multitude of social, environmental, and economic challenges facing farmers and communities. Many of Virginia's 47,000 farms, particularly its small and midlevel farms, are struggling to maintain market share and profitability (United States Department of Agriculture, 2010). In 2007, 53 percent of Virginia farms reported a net loss from their farming operations (United States Department of Agriculture, 2009). Coupled with suburban expansion, these economic conditions resulted in a loss of over 520,000 acres (210,000 hectares) of farmland across the state between 2002 and 2007 (United States Department of Agriculture, 2009). In addition to economic struggles for producers and loss of farmland, many individuals and communities throughout Virginia, especially those outside of northern Virginia, face high rates of poverty and low levels of food security. In 2010, approximately 16.7 percent of Virginia's rural population and 10.2 percent of Virginia's urban population lived in poverty (United States Department of Agriculture, 2012a). In addition, 12.9 percent of Virginia's population, or over 620,000 residents, are food insecure or have very low food security (United States Department of Agriculture, 2012a).

Across the nation, a variety of approaches and strategies are being developed to address these, and similar challenges. One strategy utilized in Virginia as well as throughout the nation has been exploring ways to revitalize agrifood systems through the enhancement of community food systems. ${ }^{1}$ A number of examples can be found that explore the role community food systems play in fostering community and economic development in Virginia. For example, food systems analyst Ken Meter conducted a study of Virginia's agriculture and food system in 2007 and found that "if Virginia consumers bought 15 percent of their food directly from local farms, farms would earn USD2.2 billion of new income" (Meter, 2007a, p. 35). Similarly, a 2007 study conducted by Virginia Cooperative Extension found that if each household in Virginia spent USD10 per week of their food budget on locally grown Virginia food, USD1.65 billion would be generated annually in direct economic impact (Benson \& Bendfeldt, 2007). Additionally, the 2007 Census of Agriculture found that Virginia's directto-consumer sales grew approximately 72 percent between 2002 and 2007, from USD16.8 million to USD28.9 million (United States Department of Agriculture, 2009). Over the last several years, Virginia has also seen dramatic increases in small and midlevel farm marketing opportunities. In August 2009, Virginia had 171 farmers' markets, nearly a doubling from 2005 when there were only 88 farmers' markets in the Commonwealth of Virginia (Benson, 2009). The United States Department of Agriculture working list of food hubs shows that Virginia is home to 17 food hubs, the most of any state in the country (United States Department of Agriculture, 2012b).

In 2010 and 2011, an interdisciplinary team of faculty, practitioners, and graduate students collaborated with the goal of completing a Virginia food system assessment and developing a Virginia Farm to Table Plan to strengthen Virginia's local and regional food systems. This team included faculty and graduate students at Virginia Tech, Virginia State University, the University of Virginia,

\footnotetext{
${ }^{1}$ A community food system is commonly described as "one in which sustainable food production, processing, distribution and consumption are integrated to enhance the environmental, economic, social, and nutritional health of a particular place" (Garrett \& Feenstra, 1999, p. 2).
} 
and members of the Virginia Food System Council. A Virginia Tech College of Agriculture and Life Sciences grant provided funds to help these groups collaborate with the goal of completing a Virginia Farm to Table Plan. Team members came from diverse backgrounds related to the food system, including agricultural production, agricultural economics, local government, health and nutrition, food safety, and agricultural education. Two key tenets of the Virginia food system assessment and subsequent Virginia Farm to Table Plan were that: (1) everyone should be educated about the social, environmental, and economic importance of Virginia's food system, and (2) quality food should be affordable and accessible to everyone in Virginia regardless of their socioeconomic status. Virginia Cooperative Extension, through its Community Viability program, served as an intermediary of the land-grant universities and helped to coordinate the development of the Virginia Farm to Table Plan in close collaboration with the Virginia Food System Council and its participating organizations.

A key component of the development process for the Virginia food system assessment and Virginia Farm to Table Plan was the creation and distribution of an online survey that gathered public input from agrifood stakeholder groups within the state. The goal of the survey was to identify priority strategies for strengthening Virginia's local and regional food systems in the areas of (1) production and business management; (2) market development; (3) food system planning, management, and policy; and (4) food security, food safety, diet, and health. The overall purpose of this article is to present the results of an online survey of Virginia agrifood system stakeholders that investigated their priorities for strengthening Virginia's local and regional food systems. In doing so, we review the use of surveys in statewide food system assessments and planning processes to contextualize our particular approach and findings. Following this, a discussion is offered of what the research team learned concerning the use of surveys as part of a Virginia food system assessment and planning process.

The 2007 Virginia Food Security Summit offered the opportunity for individuals from diverse food system backgrounds in Virginia to openly discuss issues affecting the sustainability of its food system (Virginia Food Security Summit, 2007). In addition to other national experts, Ken Meter of the Crossroads Resource Center was a speaker at the summit and provided participants with a comprehensive overview of Virginia's food system, as well as an in-depth macroeconomic analysis of Virginia's food imports, food exports, and economic leakages (Virginia Food Security Summit, 2007). Following this summit, a number of different organizations and groups began to work both independently and collaboratively on initiatives that would strengthen Virginia's local and regional food systems. Virginia Cooperative Extension began to offer a series of educational programs on community food systems (Virginia Cooperative Extension, 2012), a Virginia Food System Council was initiated (Virginia Food System Council, 2012), and numerous groups and organizations began to create local and regional "Buy Fresh Buy Local" chapters across Virginia (Piedmont Environmental Council, 2007-2008).

Additionally, many organizations and groups began to compile statistics related to Virginia's food systems. The purpose of these activities was to gain a more complete understanding of the conditions surrounding Virginia's food systems and to help make the case for strengthening community food systems. Although imperfectly developed and articulated, this work could be classified as completing part of a local food economy assessment as described by Freedgood, Pierce-Quiñonez, and Meter (2011). In addition to other research activities, this included asking Ken Meter to complete two local food economy assessments in the Martinsville City and Henry County region (Meter, 2011a), and a 10-county cluster in Shenandoah Valley (Meter, 2010b). A previous local food economy assessment had been completed by Ken in 2007 for the East Chesapeake Bay region (Maryland and Virginia) (Meter, 2007b). Building on these activities, several Virginia groups and organizations decided to collaboratively implement a statewide food system planning process with the hopes of completing a Virginia food system assessment leading to the development of a Virginia Farm to Table Plan. 


\section{Literature Review}

\section{Comprehensive Food System Assessments}

A food system is commonly thought of as all of the processes involved with keeping us fed, including the growing, harvesting, processing, packaging, transporting, marketing, consuming, and disposing of food and food packages (Wilkins \& EamesSheavly, 2003). The purpose of a food system is to build health, wealth, connection, and capacity in our communities, but the current food system is failing on these counts (Meter, 2010a). Food system planning is an emerging field that can address these issues by engaging citizens, food policy councils, planning professionals, civic officials, and other interested individuals in a process to create more sustainable local, state, and regional food systems (Freedgood et al., 2011). Several tools can be employed by these individuals and groups to support food system planning efforts (Freedgood et al., 2011). While some of the tools use similar methodologies, the purpose of each approach is unique (Freedgood et al., 2011). One of the newest tools being employed in the United States is the implementation of a comprehensive food system assessment (Freedgood et al., 2011).

According to Freedgood, Pierce-Quiñonez, and Meter (2011), comprehensive food system assessments are an emerging technique that analyzes the systematic nature of a local, state or regional food system to address the interactions of food with social, environmental, and economic concerns. Comprehensive food system assessments oftentimes use a combination of qualitative and quantitative methodologies, such as stakeholder focus groups, interviews, and surveys, as well as geospatial analysis (Freedgood et al., 2011). Over the past decade, a number of individuals and organizations have completed these kinds of assessments that have been focused at a statewide level. Statewide food system assessments include those completed in California (American Farmland Trust, 2010; Brady, 2005), Colorado (LiveWell Colorado, 2010), Indiana (Meter, 2012), Iowa (Leopold Center for Sustainable Agriculture, 2011; Tagtow \& Roberts, 2011), Minnesota (Meter, 2009), Ohio (Meter, 2011b), and Vermont (Vermont Sustainable Jobs Fund, 2011). While the format and focus of each of these assessments are unique, each included the collection of primary data through various qualitative or quantitative research methods. Other states such as North Carolina (Curtis, Creamer, \& Thraves, 2010) and Illinois (Illinois Local and Organic Food and Farm Task Force, 2009) incorporated public feedback in the development of their statewide plans, but provide a limited description of how this information was collected and analyzed. For the purpose of this paper, we focus on three food system assessment cases that specifically use surveys as an integral component of their methodology. We now refer to these processes as comprehensive food system assessments following the criteria put forth by Freedgood, Pierce-Quiñonez, and Meter (2011).

\section{The Use of Surveys in Comprehensive Food System Assessments}

A survey was employed as part of a comprehensive food system assessment in Colorado (LiveWell Colorado, 2010), Iowa (Leopold Center for Sustainable Agriculture, 2011), and Vermont (Vermont Sustainable Jobs Fund, 2011). While the focus and goal of these surveys were different, they all collected data to identify and, in some cases, prioritize issues for strengthening the states' food systems. In turn, these issues helped shape each of the state's strategic plans or policy reports. Exploring the Colorado, Iowa, and Vermont food system plans can offer insights into how surveys can be used as one part of a comprehensive food system assessment. Table 1 details the use of surveys in each of these statewide assessments, and includes information about the survey delivery method, the type of respondents, and the number of respondents. An overview of the Colorado, Iowa, and Vermont food system assessments is described. Additionally, how these surveys gathered input to aid the development of a state food system plan is also detailed.

\section{Surveys for the Colorado Food System Assessment}

The Colorado food system assessment, and subsequent Food Policy Blueprint, was led by the nonprofit organization LiveWell Colorado (LWC). The goal of LWC is to reduce obesity in the state by promoting "healthy eating and active living" (LWC, 
Table 1. Use of Surveys in the Colorado, lowa, and Vermont Food System Assessments

\begin{tabular}{lllll}
\hline State & Plan Title & $\begin{array}{l}\text { Survey Delivery } \\
\text { Method }\end{array}$ & Type of Respondents & $\begin{array}{l}\text { Number of } \\
\text { Respondents }\end{array}$ \\
\hline Colorado & Food Policy Blueprint a & Online survey & Local, regional, and state-level organizations & 130 \\
lowa & lowa Local Food \& Farm Plan ${ }^{b}$ & Online survey & Key stakeholders and lowa residents & 586 \\
Vermont & Farm to Plate Strategic Plan c & Online survey & Vermont residents & Unknown \\
\hline
\end{tabular}

a http://about.livewellcolorado.org/sites/default/files/final-food-policy-blueprint.pdf

${ }^{\mathrm{b}} \mathrm{http}$ ://www.leopold.iastate.edu/sites/default/files/pubs-and-papers/2011-01-iowa-local-food-and-farm-plan.pdf

${ }^{c}$ http://www.vsjf.org/project-details/5/farm-to-plate-strategic-plan

2010, p. 1). LWC became interested in assessing the state's food system as a way to identify key nutrition and food policy changes that would build a more resilient and healthy food system (LWC, 2010). LWC used several surveys to gather information from local, regional, and state organizations concerning how these organizations were strengthening the food system and the challenges they faced in these efforts (LWC, 2010). Two online surveys were conducted as part of the Colorado food system assessment and plan development process. One targeted state-level organizations involved in the food system such as the Colorado Department of Education, organizations representing commodity producers, and the Colorado Department of Health. The second targeted local and regional organizations involved in the food system, such as food banks, higher education institutions, and farms. Approximately 130 organizations were represented in responses to the two surveys.

The surveys asked a number of questions concerning the existence of programs focused on increasing access to healthy food. Survey results found that organizations throughout the state were involved in numerous projects and activities, such as expanding "fresh and nutritious foods provided through emergency food services" and "developing or supporting community gardens" (LWC, 2010, p. 36). Respondents also stated that the top three strategies they would like to see in Colorado were (1) developing a "community project to connect CSA shares with lower-income residents," (2) "enhanced transportation...to connect residents to sources of healthy food," and (3) "governmental institution purchasing policies for local and/or healthy foods" (LWC, 2010, p. 36). The strategies respondents identified are focused on improving access to healthy food for all persons, especially lower-income individuals, through new infrastructure projects, public policies, and targeted programs (LWC, 2010). Each of the strategies identified in the survey provides a starting place for helping LWC and its organizational partners achieve their goal of reducing obesity in the state and promoting an environment of healthy eating.

\section{Surveys for the Iowa Food System Assessment}

The Leopold Center for Sustainable Agriculture at Iowa State University led the development of the Iowa Food and Farm Plan, which relied on public input to inform every step of the development process (Leopold Center for Sustainable Agriculture, 2011). The Iowa Local Farm and Food Plan was commissioned by the state legislature with the hope of developing policy recommendations that could easily be enacted when the session opened in January 2011 (Leopold Center for Sustainable Agriculture, 2011). The goal of the Iowa Food and Farm Plan was to develop policy recommendations and key actionable items that could strengthen Iowa's "local food economy" in a sustainable manner (Leopold Center for Sustainable Agriculture, 2011, p. 3). To achieve this goal, in addition to completing a local food economy assessment, the project team and its partners completed a comprehensive food system assessment (Freedgood et al., 2011). The comprehensive food system assessment gathered public input through an initial workshop, listening sessions, and an online survey (Leopold Center for Sustainable Agriculture, 2011). 
The Iowa surveys asked respondents to identify obstacles to achieving strong local and regional food systems, and then to provide possible strategies to overcome these obstacles. The first survey was sent to 1,608 food system stakeholders. A purposive sample of stakeholders was selected to participate in the survey, representing a range of interests such as farmers, producer associations, distributors, and elected officials. The first survey received 256 responses. A second survey was sent to the general public. Approximately 1,000 Iowa residents who were on the Leopold Center for Sustainable Agriculture mailing list were sent the survey. From this survey, another 330 usable responses were collected (Leopold Center for Sustainable Agriculture, 2011).

The majority of survey respondents ( 57 percent) were between the ages of 45 and 64 years old. The largest group of respondents (39 percent) identified themselves as farmers, ranchers, and farm-related business owners and employees. Survey results found that Iowa respondents had a high level of knowledge concerning consumer issues, crop production, and marketing. Survey respondents had little knowledge about aggregation and distribution, and processing. Survey respondents were asked to identify the top obstacles facing the sector in which they had expertise. The top obstacles identified by the largest percentage of respondents were (1) processing barriers for small producers (76 percent), (2) lack of awareness of local food systems by local governments (67 percent), and (3) one-size-fits-all standards difficult for small producers and processors to achieve (66 percent) (Leopold Center for Sustainable Agriculture, 2011, p. 42). The top obstacles identified by survey respondents can be viewed as priority areas for strengthening Iowa's local food economy in a sustainable manner.

\section{Surveys for the Vermont Food System Assessment} The Vermont food system assessment and plan was commissioned by the Vermont legislature and the governor as part of the 2009 Farm-to-Plate Initiative (Vermont Sustainable Jobs Fund, 2012). The assessment was led by the Vermont Sustainable Jobs Fund, a government program focusing on strengthening businesses involved in the green economy (Vermont Sustainable Jobs Fund, 2012). The report Farm to Plate Strategic Plan: A 10-year Strategic Plan for Vermont's Food System (2011) was developed as one way to inform the Vermont legislature on key policy initiatives that could be implemented to strengthen economic growth in agricultural industries and improve health across the state (Vermont Sustainable Jobs Fund, 2012).

Public input was obtained through interviews, focus groups, food summits, working sessions, and meetings, as well as online surveys. Overall, "strengths, weaknesses, opportunities, threats, gaps, barriers, and needs affecting Vermont's food system" were identified (Vermont Sustainable Jobs Fund, 2011, p. 36). The Vermont food system assessment project directors and authors of the Vermont Farm to Plate Strategic Plan did not delineate the findings by each data collection method employed. This makes it difficult to determine the exact findings of the surveys. The plan lists a series of objectives and strategies focused on elements of the food system, including (1) consumer demand, (2) farm inputs, (3) production, (4) processing, (5) wholesale distribution, (6) retail distribution, and (7) nutrient management (Vermont Sustainable Jobs Fund, 2011). In total, 51 objectives and 59 strategies were developed to "overcome obstacles, realize opportunities, and strengthen Vermont's food system" (Vermont Sustainable Jobs Fund, 2011, p. 36). For the full list of objectives and strategies, refer to the Vermont Farm to Plate Strategic Plan.

\section{Differences Among the Colorado, Iowa, and \\ Vermont Food System Assessment Surveys}

While the Colorado, Iowa, and Vermont food system assessments all incorporated online surveys, the goals and sampling strategies for each were different. The goal of the Colorado survey was to determine the "effectiveness of various interventions to promote access to healthy food, what appears to be immediate and winnable policy opportunities, and what they [stakeholders] would like to see advanced in Colorado" (LWC, 2010, p. 3). The primary goal of the Iowa survey was to identify obstacles that prevent Iowa from having a strong local and regional food business sector, and identify strategies needed to address these obstacles 
(Leopold Center for Sustainable Agriculture, 2011). Similarly, the primary goal of the Vermont survey was to identify goals, objectives, and strategies for increasing food system development across the state (Vermont Sustainable Jobs Fund, 2011). In terms of the sampling procedure, Colorado used a purposive sample of individuals from specific local, regional, and state organizations (LWC, 2010). Iowa employed a two-stage sampling strategy, which included a purposive sample of individuals in various agrifood occupations and organizations, and a convenient sample of individuals on the Leopold Center e-newsletter mailing list (Leopold Center for Sustainable Agriculture, 2011). Authors of the Vermont study did not identify the sampling strategy they employed (Vermont Sustainable Jobs Fund, 2011).

\section{The Virginia Food System Assessment: A Focus on the Survey}

The overall goal of the Virginia project was to create a farm to table plan that prioritized strategies for strengthening Virginia's local and regional food systems. To complete this goal, five objectives were identified. One of these objectives was to gather input from Virginia's farmers, food entrepreneurs, and agrifood service providers as a way to identify important issues affecting local and regional food systems. The project team developed a survey instrument to collect input from a wide range of agrifood system stakeholders throughout Virginia. Surveys can be a useful method to gather input from a large number of individuals and easily aggregate and compile the resulting data (Creswell, 2008). The survey development and implementation process began in January 2011 and continued through March 2011.

The development phase began with a review of literature investigating the use of surveys in comprehensive food system assessments and statewide food system plans. The Virginia Farm to Table team reviewed the Colorado, Iowa, and Vermont surveys to guide the development and implementation of an online survey. A first draft of the survey instrument that was based on the Iowa survey was developed in late January 2011. To ensure the content validity of the survey, the survey was reviewed by a panel of experts consisting of 14 faculty members in Virginia Tech's College of Agriculture and Life Sciences and 24 members of the Virginia Food System Council (Virginia Farm to Table Team, 2011). The expert panel provided comments and suggestions for improvements. Additional rounds of survey drafts were created and reviewed until a final draft was completed in February 2011.

The Virginia Tech Institutional Review Board reviewed the survey and gave approval for administration of the questionnaire (\#11-103). To test the reliability of the survey, a pilot survey was administered to 17 diverse food system stakeholders attending the Shenandoah Valley Farm to Table Summit in Weyers Cave, Virginia (Virginia Farm to Table Team, 2011). After minor improvements were made following the pilot, along with additional comments and suggestions from the expert panel, the survey instrument was finalized.

The nine-page survey consisted of three major sections: (1) introduction, (2) priority rankings, and (3) demographic questions, with a total of 21 questions. In section one, three introductory questions asked respondents to confirm their residency, zip code, and email address to ensure that each respondent was unique and a resident of Virginia. In section two, the survey instrument assessed what Virginia respondents considered to be priorities for strengthening and developing local and regional food systems. Respondents were asked to rate 34 items using a four-point Likert scale (ranging from 1 as not important to 4 as very important) in four major food system categories: business production and management; market development; food system planning, management, and policy; and food security, food safety, diet, and health. A fifth column with a "not applicable" option was included for each item to allow respondents to indicate that the particular item was not a priority. Additionally, an open-ended question was added to the end of each category to allow respondents to identify additional priority items for strengthening Virginia's food systems. In section three, respondents were asked to complete a set of demographic questions.

Survey distribution occurred via email through the project directors. A two-stage sampling strategy was used. The first stage involved a purposive 
sample of individuals affiliated with diverse agrifood groups and organizations, and the second stage involved a convenient sample of individuals familiar with Virginia Cooperative Extension and the general public. This sampling strategy was chosen rather than a full random sample of Virginia households because of limited time and resources available. In order to mediate the limitations of using this sampling strategy, the project team used other methods to gather input from a broader range of Virginia residents for the Virginia Farm to Table Plan. A web address to the online survey was embedded in an invitation letter that was sent to all project partners. Project partners were asked to share the invitation with colleagues, local and regional food system networks, and other agrifood system stakeholders. Diverse food system stakeholder groups from agriculture, food and nutrition, public health, community development, natural resources, and policy were invited to complete the survey. Major universities and organizations that helped facilitate the distribution of the survey instrument included Virginia Tech, Virginia State University, the University of Virginia, the Virginia Food System Council, Virginia Cooperative Extension, Virginia Farm Bureau, Virginia Department of Agriculture and Consumer Services, Virginia Natural Resources Leadership Institute, Virginia
Municipal League, Virginia Association of Counties, Virginia Association for Biological Farming, the Center for Rural Virginia, and the Virginia Department of Mines Minerals, and Energy. Additionally, the survey was made available at the listening sessions, forums, and farm-to-table summits that were held across the Commonwealth. Furthermore, the survey was also made available through social media. Survey distribution took place over three weeks with an initial survey invitation in week one, and two follow-up reminders at the beginning of weeks two and three. Survey design and distribution followed guidelines provided by Dillman, Smyth, and Christian (2009).

\section{Results}

Data for this study were analyzed using the SPSS statistical package. To test the survey instrument for reliability, a Cronbach's Alpha statistic was computed from the pilot responses. On a Cronbach's Alpha scale ranging from zero to one, with zero indicating low reliability among the items within a survey and one indicating high reliability among the items within the survey, the computed Cronbach's Alpha was 0.93 , indicating the survey items were extremely reliable. A total of 1,374 individuals accessed the online survey instrument during the time it was available. Of these respondents,

\section{Figure 1. Map of Zip Codes with at Least One Respondent to the Virginia Food System Survey $(\mathrm{N}=1,134)$}

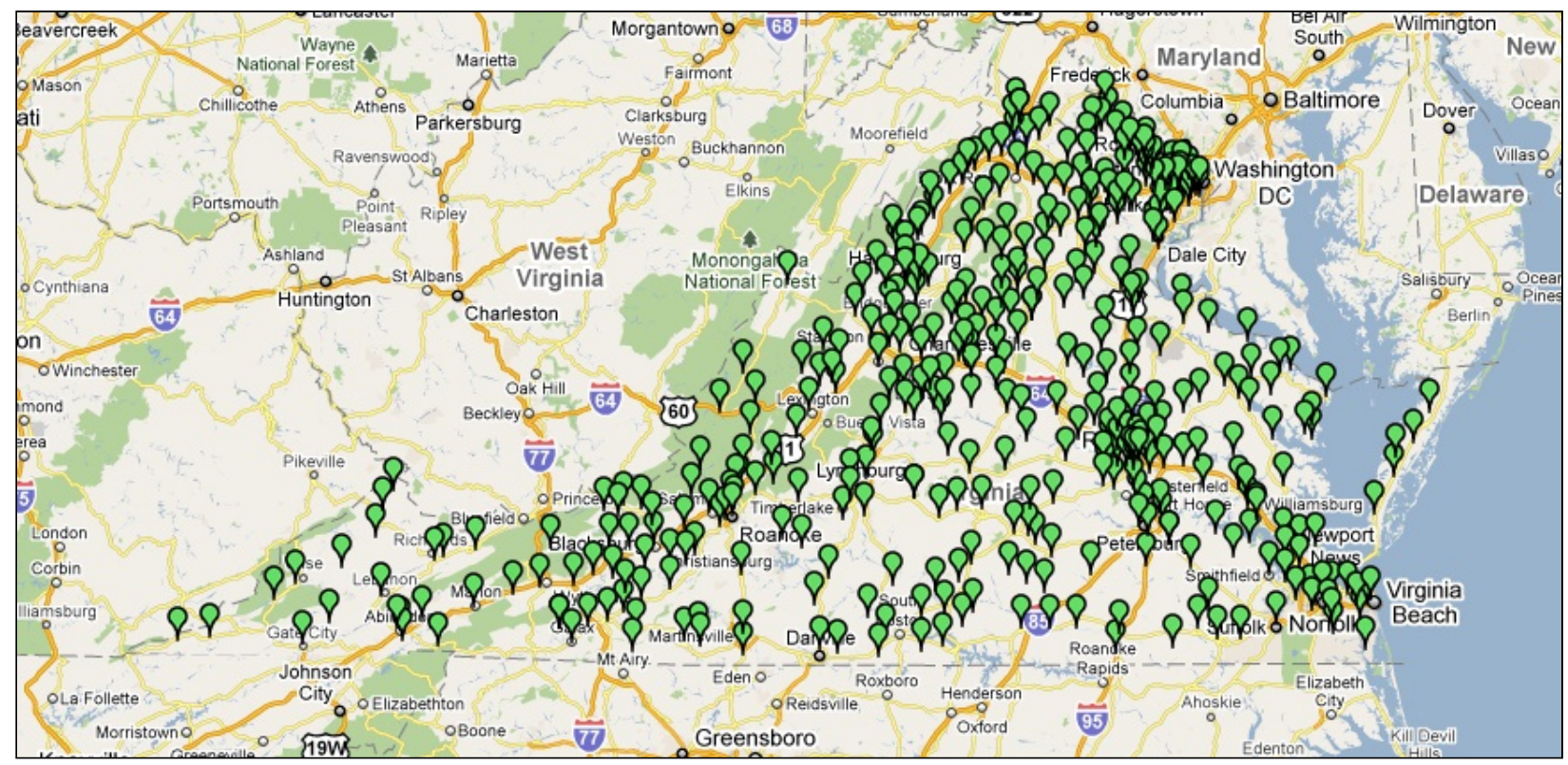


98 percent $(\mathrm{n}=1,347)$ were Virginia residents. The responses of individuals who indicated they were Virginia residents and supplied an email address $(\mathrm{N}=1,134)$ were used in the data analysis. Figure 1 shows the reported location of each respondent. A pin indicates each zip code that had at least one individual respond to the survey. In total, respondents were located in 418 unique zip codes across Virginia. It is important to note that while 1,347 respondents were included in the analysis of the study, not all of the respondents completed the survey.

Survey respondents tended to be female (approximately 60 percent, $n=465$ ) and predominantly self-identified as Caucasian or white (92.4 percent, $n=685$ ). While the respondents tended to be female, within Virginia's population, gender is almost evenly split between men and woman. Additionally, it is important to note that while the survey respondents tended to be white, Virginia's population is much more diverse. Virginia's population is made up of approximately 68.6 percent white residents, 19.4 percent African American residents, 0.4 percent American Indian and Alaska native residents, 5.5 percent Asian residents, and 7.9 percent Hispanic or Latino residents (United States Census Bureau, 2010). The survey respondents are not representative of the more than 30 percent of residents of color living in Virginia. The majority of the respondents (63 percent) were older than 45 years of age $(n=490)$. It is also important to note that the average age of Virginia residents tends to be younger than the average age of the survey respondents. Table 2 describes the demographics of Virginia residents compared to the survey respondents by the gender, age, and race and ethnicity (United States Census Bureau, 2010).

Respondents were asked their primary function within Virginia's food system. These functions broke down into three primary areas: (1)

Table 2. Virginia Demographics Compared to Survey Respondents

\begin{tabular}{|c|c|c|c|}
\hline Gender & $\begin{array}{c}\text { Virginia } \\
\text { Demographics }\end{array}$ & $\begin{array}{l}\text { Percentage of } \\
\text { Respondents }\end{array}$ & $\begin{array}{l}\text { Number of Respondents } \\
\qquad(n=774)\end{array}$ \\
\hline Female & $50.9 \%$ & $60.1 \%$ & 465 \\
\hline Male & $49.1 \%$ & $39.9 \%$ & 309 \\
\hline Age & $\begin{array}{c}\text { Virginia } \\
\text { Demographics }\end{array}$ & $\begin{array}{l}\text { Percentage of } \\
\text { Respondents }\end{array}$ & $\begin{array}{l}\text { Number of Respondents } \\
\qquad(n=778)\end{array}$ \\
\hline 18 to 24 years old & $7.2 \%$ & $4.1 \%$ & 32 \\
\hline 25 to 34 years old & $20.9 \%$ & $14.4 \%$ & 112 \\
\hline 35 to 44 years old & $13.8 \%$ & $18.5 \%$ & 144 \\
\hline 45 to 54 years old & $15.1 \%$ & $28.4 \%$ & 221 \\
\hline 55 and older & $24.3 \%$ & $34.6 \%$ & 269 \\
\hline Race and Ethnicity & $\begin{array}{c}\text { Virginia } \\
\text { Demographics }\end{array}$ & $\begin{array}{l}\text { Percentage of } \\
\text { Respondents }\end{array}$ & $\begin{array}{l}\text { Number of Respondents } \\
\qquad(n=741)\end{array}$ \\
\hline White & $68.6 \%$ & $92.4 \%$ & 685 \\
\hline African American or Black & $19.4 \%$ & $3.1 \%$ & 23 \\
\hline American Indian or Alaska Native & $0.4 \%$ & $1.9 \%$ & 14 \\
\hline Hispanic/Latino & $7.9 \%$ & $1.2 \%$ & 9 \\
\hline Asian & $5.5 \%$ & $0.7 \%$ & 5 \\
\hline Native Hawaiian or Pacific Islander & $0.1 \%$ & $0.4 \%$ & 3 \\
\hline Non-Hispanic/Latino & & $0.3 \%$ & 2 \\
\hline
\end{tabular}

a The Virginia demographic information comes from 2010 United States Census (United States Census Bureau, 2010).

$\mathrm{b}$ The statistics reported in this category within the Virginia demographics section represent individuals between 20 and 24 years of age. This is how the United States Census Bureau reports ages for these individuals. 
preharvest, including farmers and producers, (2) postharvest, including processors, distributors, and wholesalers; and (3) service and consumption, including members of food service, advocates, and educators. The majority of the respondents (64 percent) stated their primary function was within the service and consumption sector $(n=730)$. Approximately 33 percent of respondents identified themselves as part of the preharvest sector $(n=372)$. Three percent of the respondents stated their role was in the postharvest sector of the food system ( $\mathrm{n}=32)$. When asked about their occupation within the food system, approximately one-half of the respondents (44 percent) identified themselves as farmers, producers, growers, or marketgardeners. Approximately 23 percent of respondents identified themselves as working in higher education, 8 percent of the respondents identified themselves as working in prekindergarten through secondary (preK-12) educational institutions, and approximately 8 percent of the respondents identified themselves as working in local government. Table 3 describes the respondents' primary function and occupation within the food system.

The scores given by respondents were analyzed to determine which items received the highest mean score or were ranked as the highest level of importance. Table 7 in the appendix offers a full list of the 34 items ranked in order as determined by survey respondents, as well as the category in which the item appeared, mean score for the item, and coefficient of variation (CV). Coefficient of variation is the simplest way to compare standard deviations on measures that have different means (Howell, 2010). Respondents rated increasing the "understanding by government officials of the economic, environmental, and social issues surrounding local food systems" as the most important priority among all items (mean $=3.63$, $\mathrm{CV}=17.6$ percent). They rated the "development of food outlets with local and regional foods" as the second highest priority (mean $=3.61, \mathrm{CV}=18.0$ percent), and determining the "economic impacts of local and regional food systems on localities" as the third highest priority (mean $=3.53, \mathrm{CV}=18.2$ percent). These three items represent a starting place for Virginia's agrifood organizations to strengthen the state's local and regional food systems through new education, policy, and research efforts. Within the top 10 most important items, eight of the items came from the food system planning, management and policy (FSP) and market development (MD) categories. Only two of the top 10 items came from the business and production management (BPM) and food security, food safety, diet, and health (FS) categories.

The overall priority rankings for each of the four categories were then calculated. This was done to determine which categories the survey respondents rated as the most important. The category

\section{Table 3. Respondents' Primary Function and Occupation within the Virginia Food System}

\begin{tabular}{lrr}
\hline Primary Function of Respondents within Food System & Percentage & Number (N=1,134) \\
\hline $\begin{array}{l}\text { Service and consumption: Retail, institutional, lender, supplier, food service, } \\
\quad \text { advocate, technical assistance provider, educator, extension representative }\end{array}$ & $64.4 \%$ & 730 \\
Preharvest: farmer, producer, grower, market-gardener & $32.8 \%$ & 372 \\
Postharvest: processor, aggregator, distributor, wholesaler & $2.8 \%$ & 32 \\
\hline Occupation of Respondents within the Food System & Percentage & Number (n=623) \\
\hline Farmer producer, grower, market-gardener & $43.8 \%$ & 273 \\
Higher education (college, university, cooperative extension) & $23.4 \%$ & 146 \\
Education (preK-12) & $8.4 \%$ & 52 \\
Local government & $7.7 \%$ & 48 \\
Food service & $6.6 \%$ & 41 \\
State government & $5.9 \%$ & 37 \\
\hline
\end{tabular}


Table 4. Priority Ranking of Survey Categories by Mean Score (Most important to less important)

\begin{tabular}{|c|c|c|c|}
\hline Rank & & Mean & CV \\
\hline 1 & $\begin{array}{l}\text { Food System Planning, Manage- } \\
\text { ment, and Policy (FSP) }\end{array}$ & 3.31 & $19.0 \%$ \\
\hline 2 & Market Development (MD) & 3.25 & $18.3 \%$ \\
\hline 3 & $\begin{array}{l}\text { Food Security, Food Safety, Diet, } \\
\& \text { Health (FS) }\end{array}$ & 3.17 & $21.7 \%$ \\
\hline 4 & $\begin{array}{l}\text { Business and Production } \\
\text { Management (BPM) }\end{array}$ & 3.11 & $22.5 \%$ \\
\hline
\end{tabular}

with the highest rated items (i.e., most important priorities) was FSP, followed by MD and then FS. The category with the lowest rated items was business and production management (BPM). Table 4 lists each of these categories, as well as their corresponding cumulative mean score and CV. A oneway ANOVA was conducted to determine if the mean scores for each category are statistically different and found that there was no statistically significant difference between the group means.

Analyses were conducted to compare the mean scores of respondents with different occupations. Table 5 describes how respondents with different occupations prioritized each of the four categories within the survey instrument. Respondents who identified themselves as a (1) farmer producer, grower, market-gardener, (2) food processor, packer, distributor, shipper, (3) food service representative, (4) state government official, or (5) local government official rated items in the FSP category
Table 6. Priority Ranking of Survey Categories by Respondents' Age

\begin{tabular}{lllll}
\hline & BPM a & MD $b$ & FSP $~$ & FS d \\
\hline 18-24 years of age & 3.15 & 3.19 & $3.50 * 3.31$ \\
25-34 years of age & 2.93 & $3.19 * 3.07$ & 3.16 \\
35-44 years of age & 2.94 & $3.23 *$ & 3.22 & 3.04 \\
45-54 years of age & 3.00 & 3.16 & $3.22 * 3.13$ \\
55+ years of age & 3.03 & 3.25 & $3.31 * 3.15$ \\
\hline
\end{tabular}

a Business and production management; ${ }^{b}$ Market development; c Food system planning, management, and policy; ${ }^{d}$ Food security, food safety, diet and health.

* Highest rated category for each respondent group.

as the highest or most important priorities.

Respondents who identified themselves as working in education (preK-12) rated items in the category of MD as the highest or most important priorities. Respondents working in higher education (college, university, cooperative extension) rated items in FS as the highest or most important priorities.

Analyses were also conducted comparing the mean scores of respondents by age. Table 6 describes how respondents in different age categories prioritized each of the four categories within the survey instrument. Respondents 18 to 24 years of age rated items in the FSP category as the highest or most important. Respondents between 25 to 44 years of age rated items in the MD category as the highest or most important. Respondents 45

Table 5. Priority Ranking of Survey Categories by Respondents' Occupation

\begin{tabular}{|c|c|c|c|c|}
\hline & BPM a & MD b & FSP c & FS $d$ \\
\hline Farmer producer, grower, market-gardener & 3.07 & 3.21 & $3.28 *$ & 3.12 \\
\hline Food processing, packaging, distribution, shipping & 2.91 & 3.32 & $3.36 *$ & 3.19 \\
\hline Food service & 2.82 & 3.16 & $3.24 *$ & 3.18 \\
\hline State government & 3.37 & 3.34 & $3.42 *$ & 3.12 \\
\hline Local government & 3.09 & 3.31 & $3.42 *$ & 3.22 \\
\hline Education (preK-12) & 3.14 & $3.34 *$ & 3.22 & 3.33 \\
\hline Higher education (college, university, cooperative extension) & 2.95 & 3.23 & 3.19 & 3.29 \\
\hline
\end{tabular}

a Business and production management; ${ }^{b}$ Market development; ${ }^{c}$ Food system planning, management, and policy; ${ }^{d}$ Food security, food safety, diet and health.

* Highest rated category for each respondent group. 
and older also rated items in the FSP category as the most important.

\section{Discussion}

Overall, respondents rated (1) food system planning, management, and policy (FSP), and (2) market development (MD) as the most important priority areas for strengthening Virginia's food systems. Respondents rated increasing the "understanding by government officials of the economic, environmental, and social issues surrounding local food systems" as the most important priority among all of the items listed. These results indicate that respondents view the most pressing food system issues to be related to off-farm needs. This is significant from our perspective because it identifies the need to collaborate and connect with a wider variety of individuals who may not be directly related to agricultural and food production but who can play a vital role in strengthening Virginia's local and regional food systems. The Virginia survey results also reveal that respondents would like local and state policymakers to fully understand the impacts of local and regional food systems and begin to strengthen Virginia agriculture through innovative policies that promote strong farm to table connections. ${ }^{2}$

The goal, sampling strategy, and results of the Virginia survey can be compared to the Colorado, Iowa, and Vermont surveys. The goal of the Virginia survey was similar to the Iowa and Vermont surveys, which involved identifying priority issues and strategies for strengthening local and regional food systems. In contrast, the goal of the Colorado survey was to identify action items to promote access to healthy food. Virginia employed a similar sampling strategy as Iowa, using first a purposive sample of targeted groups and organizations, followed by a convenient sample of the general public. The Virginia survey found the most important priority to be increasing the "understanding by government officials of the economic, environmental, and social issues surrounding local food systems." This result is similar to one of the priorities identified in the Iowa survey, which was a

${ }^{2}$ For further discussion on these issues, see the Virginia Farm to Table Plan (2012). lack of awareness of local food systems by local governments. In contrast, other results of the Iowa survey were different than those found in Virginia. These differences may be due to a number of reasons, including the unique characteristics of each state's agrifood system.

In recent decades, land-grant universities have been criticized for being slow to respond to recent restructuring in the food system, and some people have begun to question their ability to fulfill their institutional mission (Colasanti, Wright, \& Reau, 2009). However, in the midst of change within higher education, the Cooperative Extension Service, and the agrifood system, new opportunities are blossoming around strengthening local and regional food systems. As was shown through the survey and subsequent development of the Virginia Farm to Table Plan, land-grant universities and Cooperative Extension professionals can be effective in convening, coordinating, and leading efforts to work collaboratively with other organizations and other state agencies on community food system issues (Dunning, Creamer, Lelekacs, O'Sullivan, Thraves, \& Wymore, 2012).

Developing a survey instrument as part of the Virginia Farm to Table Plan development process provided an opportunity for a diverse group of faculty, practitioners, and stakeholders across the food system to address agrifood system issues. The survey development and implementation process was initiated after diverse Virginia groups and organizations hosted a series of educational programs on community food systems, worked with state organizations to compile statistics about Virginia's food system, and worked with food system analyst Ken Meter to complete several local food economy assessments. These steps were critical in providing a strong foundation to complete a Virginia food system assessment and subsequent Virginia Farm to Table Plan. Other land-grant universities, Cooperative Extension Systems, and community-based and nonprofit organizations can use this survey instrument and plan development process as a framework to address agrifood system issues with the aim of strengthening local and regional food systems.

From our experiences, we found it helpful to create a collaborative team with individuals from 
multiple backgrounds related to the food system. Individuals from different disciplines represented expertise in health and nutrition, local and state government, agricultural production and distribution, and community economic development. We also found it helpful to include representation from numerous higher education institutions and organizations from across Virginia such as Virginia Tech, Virginia State University, the University of Virginia, Virginia Cooperative Extension, and the Virginia Food System Council. Each university and organization had connections to stakeholders, organizations, and resources throughout the state, and we believe that these connections were one reason the survey instrument received a high number of responses. We also found that Cooperative Extension played an instrumental role in supporting the statewide food system assessment.

\section{Conclusions}

This study provides specific food system priority areas that can be addressed by policymakers, as well as priority areas that can be addressed by research and educational programs through landgrant universities, Cooperative Extension Systems, and community-based organizations. The importance of this study was alluded to in many of the comments provided by respondents in the openended questions within the survey. Many of the comments related to the need for more education and outreach. Comments included "there needs to be educational programs to inform potential growers/producers about the local food movement," "motivation and education are needed to help this movement grow," "need peer-to-peer collaborative learning opportunities," and "just think outside the box." The respondents reinforce the point that opportunities exist for land-grant universities, Cooperative Extension Systems, and community-based organizations to expand educational programming and develop informational campaigns focused on strengthening sustainable local and regional food systems.

The findings of this study show that people's connection to purchasing locally or regionally produced food is part of a greater movement currently taking place in Virginia and throughout the U.S. Respondents represent a large number of residents from a diverse set of backgrounds and over 400 zip codes across the Commonwealth. The number of respondents who completed the Virginia food system survey $(\mathrm{N}=1,134)$ was considerably higher than the number of respondents that completed similar surveys in other states such as Iowa $(\mathrm{N}=586)$ and Colorado $(\mathrm{N}=130)$. Although Virginia received a greater number of responses compared to Iowa and Colorado, according to the 2010 U.S. Census the total population of Virginia is considerably higher (8.1 million residents) than both Iowa (3.1 million residents) and Colorado (5.1 million residents). The high number of responses may be due to the collaborative nature of the groups involved in strengthening Virginia's local and regional food systems, as well as the extensive networks established by project directors and partners who were activated to distribute the survey invitation. This high number of responses may also be due to residents and stakeholders identifying with the work or the individuals and organizations involved. Other states may want to explore working with the Cooperative Extension System and land-grant universities to develop initiatives related to community food systems.

While this food system assessment can be most closely classified as a comprehensive food system assessment following the typology developed by Freedgood, Pierce-Quiñonez, and Meter (2011), we believe that a new category may need to be created that fully reflects the trend of states creating their own food system plan. While statebased food system plans may use methods similar to comprehensive food system assessments, their focus is slightly different. The primary purpose of developing a state food system plan is often to determine a set of actions or strategies that agrifood system stakeholders can pursue for strengthening local and regional food systems, rather than strictly analyzing "the systemic nature of a local, state, or regional food system, including the land requirements, production, processing, distribution, consumption, and disposal of waste" (Freedgood et al., 2011, p. 86). When developing priorities for strengthening a state's local and regional food systems, we suggest that agrifood system stakeholders consider "the interactions of food with social, envi- 
ronmental, and economic concerns" (Freedgood et al., p. 86).

It is important to acknowledge and understand the limitations of this study. First, a limitation comes from the sampling strategy used to collect survey responses. Time and funding restrictions limited the development and implementation of a full random sample of Virginia households. Instead of a random sampling method, the team utilized a two-stage sampling method. This approach, which incorporated purposive and convenient samples, limits the external validity of the results, and we cannot claim that these results represent the entire population of Virginia. Second, this study is limited by the nonrepresentative sample collected from the survey questionnaire. Although considerable care was taken to try and receive a representative sample, this was not achieved. As previously mentioned, Virginia's population can be classified as approximately 69 percent white individuals and 31 percent individuals of color (United States Census Bureau, 2010). Additionally, it can be classified as almost evenly split between male and female (United States Census Bureau, 2010). The majority of the respondents of the survey identified themselves as white individuals (92.4 percent) who were female (60.1 percent). Males and respondents of color are not represented among our respondents at the same percentage as those individuals living in Virginia, and therefore the survey results fail to completely express the concerns and priorities of these populations. Because of this, our findings may accurately provide insight into the beliefs of Caucasian and female individuals in Virginia, but may not represent the diversity of views of all individuals living in Virginia. Third, survey results are limited by the unequal distribution of stakeholder groups that responded to the survey. For example, far more respondents identified themselves as having service and consumption as their primary function within the food system, compared to respondents who identified themselves as either involved with preharvest or postharvest functions. Our results are limited by this unequal distribution, and we acknowledge this may have skewed the results away from prioritizing on-farm agricultural production and processing needs. Fourth, this food system assessment is limited in that it does not analyze the business assets nor the views of Virginia business leaders. To help combat these limitations while developing the Virginia Farm to Table Plan, several other types of data collection methods were employed, including local and regional focus group and listening sessions, and farm-to-table summits to ensure that the Virginia Farm to Table Plan represented the views of multiple audiences. Even with the use of convenient sampling method and the lack of diversity in respondents, the large sample size represents food system stakeholders from every region of Virginia and provides a substantial baseline to determine the most pressing priority areas to strengthen and further develop Virginia's local and regional food systems.

Future research could focus on several issues that were not addressed in this study, as well as issues related to the limitations of this study. An indepth assessment of Virginia's local and regional food systems could be completed using a full random sample to ensure that all groups in Virginia have the opportunity to provide input into the priority strategies employed to strengthen Virginia's local and regional food systems and to allow for externally valid results. Additionally, an in-depth assessment could be completed for each of the four categories contained within the survey. Furthermore, an in-depth assessment could be completed that investigates and prioritizes business strategies and initiatives for strengthening Virginia's local and regional food systems. Finally, specific assessments of the diverse organizations and groups involved with Virginia's food system could be completed to better understand priority areas within each stakeholder group and allow for a greater understanding of priorities for strengthening Virginia's local and regional food systems.

\section{Acknowledgements}

Funding for this research was provided through the Virginia Tech College of Agriculture and Life Sciences Integrated Internal Competitive Grants Program. The authors of this paper are grateful for the support of the Virginia Farm to Table project partners, the Virginia Food System Council and its affiliate organizations, and the Virginia Cooperative Extension Community Viability Program. The 
authors would like to acknowledge and thank the Virginia Tech College of Agriculture and Life Sciences faculty who supported the development of the Virginia Farm to Table Plan, including Susan Clark, Joe Eifert, Jonah Fogel, Steven Hodges, Francie Kennedy, Kenner Love, Theresa Nartea, Jactone Ogejo, Elena Serrano, Amber Vallotton, and Pete Ziegler. The authors are grateful for the support of Dr. Mido Chang, Virginia Tech Associate Professor in the Educational Research and Evaluation Program. Additionally, the authors are grateful to the reviewers of the Journal of Agriculture, Food Systems, and Community Development for their suggestions and comments, which greatly improved the quality of this manuscript. 


\section{Appendix}

\section{Table 7. Priority Ranking of Survey Items by Mean Score (Most important to less important)}

\begin{tabular}{|c|c|c|c|c|}
\hline Rank & Item & Category a & Mean & CV \\
\hline 1 & $\begin{array}{l}\text { Understanding by government officials of the economic, environmental, and } \\
\text { social issues surrounding local food system. }\end{array}$ & FSP & 3.63 & $17.6 \%$ \\
\hline 2 & Development of food outlets with local and regional foods. & MD & 3.61 & $18.0 \%$ \\
\hline 3 & Economic impacts of local and regional food systems on localities. & FSP & 3.53 & $18.2 \%$ \\
\hline 4 & $\begin{array}{l}\text { Training, knowledge, and support to market development for local and regional } \\
\text { products. }\end{array}$ & MD & 3.53 & $18.8 \%$ \\
\hline 5 & Land-use planning and zoning considerations for food system needs. & FSP & 3.53 & $19.3 \%$ \\
\hline 6 & $\begin{array}{l}\text { Consumer focused educational programs on healthy eating and cooking with local } \\
\text { and regional foods. }\end{array}$ & FS & 3.48 & $21.3 \%$ \\
\hline 7 & Environmental impacts of local and regional systems on localities. & FSP & 3.47 & $20.4 \%$ \\
\hline 8 & $\begin{array}{l}\text { Development of markets for local and regional foods to meet the needs of } \\
\text { educational institutions and hospitals. }\end{array}$ & MD & 3.47 & $20.9 \%$ \\
\hline 9 & Education on identifying local marketing opportunities. & MD & 3.46 & $20.9 \%$ \\
\hline 10 & Training, knowledge, and support to develop comprehensive business plans. & BPM & 3.45 & $21.2 \%$ \\
\hline 11 & $\begin{array}{l}\text { Availability of USDA- and state-approved processing capabilities (flash-freeze, } \\
\text { canning, meat processing, and community kitchen). }\end{array}$ & MD & 3.44 & $22.1 \%$ \\
\hline 12 & Educational programs in whole-farm planning. & BPM & 3.42 & $21.7 \%$ \\
\hline 13 & $\begin{array}{l}\text { Business planning support to maintain public, physical, and capital infrastructure } \\
\text { for local food systems. }\end{array}$ & FSP & 3.41 & $20.9 \%$ \\
\hline 14 & Training, knowledge, and support for value-added marketing and product pricing. & MD & 3.39 & $21.0 \%$ \\
\hline 15 & Local food system planning in the localities' comprehensive plans. & FSP & 3.39 & $22.0 \%$ \\
\hline 16 & $\begin{array}{l}\text { Cost, supply, and knowledgeable workforce to prepare local, fresh, value-added } \\
\text { foods. }\end{array}$ & MD & 3.38 & $21.1 \%$ \\
\hline 17 & Consumer focused education on the cost of local and regional foods. & FS & 3.35 & $22.9 \%$ \\
\hline 18 & Local or regional food systems impact on the diet and health of consumers. & FS & 3.35 & $23.4 \%$ \\
\hline 19 & Cost and availability of insurance for producers direct selling local food products. & MD & 3.34 & $22.1 \%$ \\
\hline 20 & Affordable business loans for long-term and short-term financing. & BPM & 3.34 & $24.9 \%$ \\
\hline 21 & $\begin{array}{l}\text { Knowledge of and step-by-step procedures to meet Good Agricultural Practices } \\
\text { (GAP) certification. }\end{array}$ & BPM & 3.32 & $23.6 \%$ \\
\hline 22 & Educational programs in specialty crop production. & BPM & 3.31 & $23.9 \%$ \\
\hline 23 & $\begin{array}{l}\text { Managing or disposing of the non-consumable (waste) products generated during } \\
\text { the food production and consumption process. }\end{array}$ & FSP & 3.30 & $23.5 \%$ \\
\hline 24 & Year-round local product availability. & MD & 3.27 & $25.8 \%$ \\
\hline 25 & Training, knowledge, and support to obtain loans for local food enterprises. & BPM & 3.27 & $25.9 \%$ \\
\hline 26 & $\begin{array}{l}\text { Food safety practices for local foods (food storage, preparation, preservation) } \\
\text { targeted at consumers. }\end{array}$ & FS & 3.23 & $25.4 \%$ \\
\hline 27 & Educational programs in animal/livestock husbandry. & BPM & 3.22 & $25.3 \%$ \\
\hline 28 & $\begin{array}{l}\text { Commercial education about safely producing, preparing, and storing local and } \\
\text { regional foods. }\end{array}$ & FS & 3.20 & $24.8 \%$ \\
\hline 29 & Benchmark data to support local food business financing. & BPM & 3.17 & $25.0 \%$ \\
\hline
\end{tabular}


Journal of Agriculture, Food Systems, and Community Development ISSN: 2152-0801 online

www.AgDevJournal.com

\begin{tabular}{|c|c|c|c|c|}
\hline Rank & Item & Category a & Mean & CV \\
\hline 31 & Access to food system market research for localities. & FSP & 3.10 & $25.2 \%$ \\
\hline 32 & $\begin{array}{l}\text { Consumer education and training on food budgeting and food assistance } \\
\text { programs. }\end{array}$ & FS & 3.05 & $28.7 \%$ \\
\hline 33 & $\begin{array}{l}\text { Research on food safety risks to consumers within a local or regional food } \\
\text { system. }\end{array}$ & FS & 2.97 & $30.2 \%$ \\
\hline 34 & $\begin{array}{l}\text { Implementing a tracking system for products as they travel through the supply } \\
\text { chain. }\end{array}$ & MD & 2.82 & $33.9 \%$ \\
\hline
\end{tabular}

a Abbreviations: BPM = business and production management; FS = food security, food safety, diet, and health; FSP = food system planning, management and policy; $\mathrm{MD}=$ market development 


\section{References}

American Farmland Trust. (2010). California agricultural vision: Strategies for sustainability. Retrieved from the California Department of Food and Agriculture website: http://www.cdfa.ca.gov/agvision

Benson, M. (2009). The growing attention to food and agriculture: Examining Virginia's direct marketing industry. Farm Business Management Update, August-September 2009, Virginia Cooperative Extension. Retrieved from Virginia Cooperative Extension website: http://www.ext.vt.edu/

Benson, M., \& Bendfeldt, E. (2007). Annual community food dollars generated if each household in Virginia spent $\$ 10 /$ week of their total food dollars on fresh local produce and farm-based Virginia products. Virginia Cooperative Extension Bulletin.

Brady, E. (2005). The new mainstream: A sustainable food agenda for California for review by the Roots of Change Council and the Roots of Change Fund. Sacramento, California: The Vivid Picture Project/Ecotrust. Retrieved from http://www.vividpicture.net/ documents/The_New_Mainstream.pdf

Colasanti, K., Wright, W., \& Reau, B. (2009). Extension, the Land-Grant mission, and civic agriculture: Cultivating change. Journal of Extension, 47(4), 1-10.

Creswell, J. W. (2008). Educational research: Planning, conducting, and evaluating quantitative and qualitative research (3rd Ed.). Upper Saddle River, New Jersey: Pearson Education.

Curtis, J., Creamer, N., \& Thraves, T. E. (2010). From farm to fork: A guide to building North Carolina's sustainable local food economy. Retrieved from the Center for Environmental Farming Systems website: http://www.cefs.ncsu.edu/resources/ stateactionguide2010.pdf

Dillman, D. A., Smyth, J. D., \& Christian, L. M. (2009). Internet, mail, and mixed-mode surveys: The tailored design method. Hoboken, New Jersey: John Wiley \& Sons.

Dunning, R., Creamer, N., Lelekacs, J. M., O’Sullivan, J., Thraves, T., \& Wymore, T. (2012). Educator or institutional entrepreneur: Cooperative extension and the building of localized food systems. Journal of Agriculture, Food Systems, and Community Development, 3(1), 1-14. http://dx.doi.org/10.5304/jafscd.2012.031.010

Freedgood, J., Pierce-Quiñonez, M., \& Meter, K. A. (2011). Emerging assessment tools to inform food system planning. Journal of Agriculture, Food Systems, and Community Development, 2(1), 83-104. http://dx.doi.org/10.5304/jafscd.2011.021.023

Garrett, S., \& Feenstra, G. (1999). Growing a community food system. Pullman, Washington: Western Rural Development Center.

Howell, D. C. (2010). Statistical methods for psychology. Belmont, California: Cengage Wadsworth.

Illinois Local and Organic Food and Farm Task Force. (2009). Local food, farms \& jobs: Growing the Illinois economy. Retrieved from the Local Food, Farms \& Jobs: Growing the Illinois Economy website: http://foodfarmsjobs.org/wp-content/uploads/ 2011/08/2009-task-force-report1.pdf

Leopold Center for Sustainable Agriculture. (2011). Iowa's local food \& farm plan: Report to the Iowa Legislature from the Leopold Center for Sustainable Agriculture, January 2011. Retrieved from http://www.leopold.iastate.edu/foodandfarmplan. $\underline{\mathrm{html}}$

LiveWell Colorado [LWC]. (2010). Food policy blueprint, January 2010. Retrieved from https://about.livewellcolorado.org/

Meter, K. (2007a). Economic leakage in Virginia's food economy. Retrieved from the Crossroads Resource Center website: http://www.crcworks.org/crcppts/va07.pdf

Meter, K. (2007b). Food and farm economy of the east Chesapeake Bay region. Retrieved from the Crossroads Resource Center website: http://www.crcworks. org/crcdocs/mdchessum07.pdf

Meter, K. (2009). Mapping the Minnesota food industry. Retrieved from the Crossroads Resource Center website: http://www.crcworks.org/mnfood.pdf

Meter, K. (2010a). Promising community-based food system initiatives. Retrieved from the Crossroads Resource Center website: http://www.crcworks.org/promising.pdf

Meter, K. (2010b). Shenandoah V alley (Virginia) local farm \& food economy. Retrieved from the Crossroads Resource Center website: http://www.crcworks. org/crcdocs/vashensum10.pdf

Meter, K. (2011a). Martinsville/Henry County region (Virginia \& North Carolina) local farm \& food economy. Retrieved from the Crossroads Resource Center website: http://www.crcworks.org/crcdocs/ vancsum11.pdf 
Meter, K. (2011b). Obio's food systems_-Farms at the heart of it all. Retrieved from http://www.crcworks.org/ ohfood.pdf

Meter, K. (2012). Hoosier farmer? Emergent food systems in Indiana. Retrieved from http://www.crcworks.org/ infood.pdf

Piedmont Environmental Council. (2007-2008). Buy fresh buy local - Virginia - Buy local Virginia. Retrieved from the Buy Fresh Buy Local for the State of Virginia website: http://www.buylocalvirginia.org

Tagtow A., \& Roberts S. (2011). Cultivating resilience: $A$ food system blueprint that advances the bealth of Iowans, farms and communities. Retrieved from the Iowa Food Systems Council website: http://www.iowafood systemscouncil.org/cultivating-resilience

United States Census Bureau. (2010). Census Bureau home page. Retrieved from http://www.census.gov

United States Department of Agriculture. (2009). 2007 census of agriculture: United States summary and state data (Report No. AC-07-A-51). Retrieved from http://www.agcensus.usda.gov/Publications/ 2007/index.asp

United States Department of Agriculture. (2010). 2010 state agriculture overview: Virginia. Retrieved from http://www.nass.usda.gov/Statistics by State/ Ag Overview/AgOverview VA.pdf

United States Department of Agriculture. (2012a). State fact sheets: Virginia. Retrieved from http://www.ers.usda.gov/StateFacts/VA.HTM

United States Department of Agriculture. (2012b). Working list of food hubs (online report, updated 1 September 2012). Retrieved from http://www.ams.usda.gov/AMSv1.0/foodhubs
Vermont Sustainable Jobs Fund. (2011). Farm to plate strategic plan: A 10-year strategic plan for Vermont's food system, January 2011. Retrieved from http://www.vsjf.org

Vermont Sustainable Jobs Fund. (2012). Vermont sustainable jobs fund website home page. Retrieved from http://www.vsjf.org

Virginia Cooperative Extension. (2012). Community food system and enterprises. Retrieved from http://www.cv. ext.vt.edu/topics/ComFoodSystems/index.html

Virginia Farm to Table Team. (2011, December). Virginia farm to table: Healthy farms and healthy food for the common wealth and common good. A plan for strengthening Virginia's local food system and economic future. E. Bendfeldt, C. Tyler-Mackey, M. Benson, L. Hightower, \& K. Niewolny (Eds.). Retrieved from Virginia Cooperative Extension website: http://pubs.ext.vt.edu/CV/CV-3/CV3 lowrez pdf.pdf

Virginia Food Security Summit. (2007). Virginia food security summit: Envisioning a sustainable food system for Virginia. Retrieved from http://www.virginia.edu/ ien/foodsummit/docs/Food\%20Summit web.pdf

Virginia Food System Council. (2012). Background and bistory. Retrieved from http://virginiafoodsystem council.org/about-us/background-and-history/

Wilkins, J. L., \& Eames-Sheavly, M. (2003). Discovering the food system: An experiential learning program for young and inquiring minds. Ithaca, New York: Cornell University. Retrieved from Cornell University's Discovering the Food System website: http://www.discoverfoodsys.cornell.edu/pdfs/ foodsys.pdf 